\title{
Some botanical aspects and antifungal activity of Etlingera flexuosa (Zingiberaceae) from Central Sulawesi, Indonesia
}

\author{
RAMADANIL PITOPANG ${ }^{1, \bullet}$, UMRAH ${ }^{1}$, WAHYU HARSO ${ }^{1}$, NURAINAS ${ }^{2}$, \\ MUHAMMAD SULAIMAN ZUBAIR ${ }^{3}$ \\ ${ }^{1}$ Department of Biology, Faculty of Mathematics and Natural Sciences, Universitas Tadulako. Jl. Sukarno Hatta Km 9, Kampus Bumi Tadulako, Palu \\ 94118, Central Sulawesi, Indonesia. Tel.: +62-451-422611, 422355, Fax.: +62-451-422844, `email: pitopang_64@yahoo.com. \\ ${ }^{2}$ Department of Biology, Faculty Mathematics and Natural Sciences, Universitas Andalas. Jl. Raya Unand, Kampus Limau Manih, Padang 25163, West \\ Sumatra, Indonesia \\ ${ }^{3}$ Department of Pharmacy, Faculty of Mathematics and Natural Sciences, Tadulako University. J1. Sukarno Hatta Km 9, Kampus Bumi Tadulako, Palu \\ 94118, Central Sulawesi, Indonesia
}

Manuscript received: 6 May 2020. Revision accepted: 13 July 2020.

\begin{abstract}
Pitopang R, Umrah, Harso W, Nurainas, Zubair MS. 2020. Some botanical aspects and antifungal activity of Etlingera flexuosa (Zingiberaceae) from Central Sulawesi, Indonesia. Biodiversitas 21: 3547-3553. Etlingera flexuosa is a species of Etlingera endemic to the island of Sulawesi and its natural distribution is restricted to Central and South Sulawesi, where it has been utilized for different purposes. Despite the limited knowledge in the aspects of botany and its antimicrobial activities, the use of plants as a source of alternative solutions to health problems is on the rise. The objectives of this study were to obtain some information about the several botanical aspects of E. flexuosa and its antifungal activity. This research was conducted from March to December 2019 and samples were collected from the montane forest of Lore Lindu National Park (LLNP) near Sedoa Village, Lore Utara Sub-district, Poso District, Indonesia. The identification of plant specimens and extractions was carried out at the Laboratory of Plant Biosystematics, Tadulako University, Palu, Indonesia. The antifungal activity was tested using agar diffusion methods. The results showed that $E$. flexuosa is a perennial herb naturally distributed in Sulawesi island. It usually grows in the pristine submontane and montane forests, sometimes in light and open condition or on the slope of natural disturbed forest at the altitude of $1500-1700 \mathrm{~m}$ a.s.l. The forest is dominated by Fagaceae family, of which E. flexuosa has been utilized extensively by local community of Topo Baria ethnic for various purposes such as flavor enhancer in food, vegetable, traditional medicine, and as roofing materials. It contains some secondary metabolites such as flavonoids, tannins, saponins, terpenoids, alkaloids and steroids, and also shows antioxidant activity. Conclusively, the extract of $E$. flexuosa could be used as inhibiting agent for the growth of Candida albicans yeast.
\end{abstract}

Keywords: Antifungal, ethnobotany, Etlingera flexuosa, phytochemical

\section{INTRODUCTION}

Zingiberaceae is a perennial herb that produces aromatic rhizomes. It is one of the families from Zingiberales order present in most tropical and subtropical regions, as well as in Southeast Asia, where there is diversity of this family. It is comprised of 53 genera, of which 26 are restricted to Malesia region and about 1,200 species of which about 1,000 occur in tropical Asia (Larsen et al. 1999). The following genera belong to Zingiberaceae; Zingiber, Alpinia, Ammomum, Boesenbergia, Curcuma, Elettaria, Etlingera, Globba, Hornstedtia, Kaempferia, Plagiostachys, and Vanoverberghia.

One of the genera belonging to Zingiberaceae family is Etlingera Giseke plant. It consists of more than 57 species, which are mainly herbs existing in tropical and subtropical zones. It is distributed across India, Burma (Myanmar), Thailand, Indo-China and China, Malaysia, Polynesia, and Australia (de Gusman and Siemonsma 1999). According to Newman et al. (2004), 74 species of Etlingera were recorded in Malesia region, including 12 species in Peninsular Malaysia (Khaw 2001), 29 species in Borneo
(Chan et al. 2007), 16 species in the Philippines (Poulsen and Docot 2018), And according to Poulsen (2012), there were estimated 150 - 200 species in total worldwide.

Etlingera flexuosa is one of 36 species of Etlingera described as new types and endemic to the island of Sulawesi. The natural distribution of the species is restricted to Central and South Sulawesi. It was previously described as a new species by Poulsen (2012) based on the specimen collected from Gunung Nokilalaki, Lore Lindu National Park Central Sulawesi province, Indonesia. It is known locally as Karondo among the Topo Baria ethnic, in Sedoa Village, Lore Utara Sub-district of Poso District, an indigenous ethnic in Central Sulawesi Indonesia.

Despite the limited knowledge about E. flexuosa from the aspects of botany such as ecology, ethnobotany, phytochemistry and its antimicrobial activities, its usage as a source of medicines is prevalent in developing countries as an alternative solution to health problems. Therefore, the objectives of the study were to obtain some information about the several botanical aspects of E. flexuosa and its antifungal activity. 


\section{MATERIALS AND METHODS}

\section{Plant materials}

The E. flexuosa sample was collected from montane forest of Lore Lindu National Park (LLNP), Central Sulawesi, near Lake Kalimpa'a, Sedoa Village, Lore Utara Sub-district, Poso District, Central Sulawesi Province, Indonesia, about $80 \mathrm{~km}$ southeastern part of Palu, the capital of Central Sulawesi, Indonesia, between March and December 2019, as shown in Figure 1. LLNP is a protected area with about 220,000 ha of land and habitat to a number of Wallacean endemic plants and animals. The area has considerable conservation value and functions as a watershed for the surrounding areas.

The botanical exploration methods have been applied in observing the population of E. flexuosa in its natural habitat. Parameters observed and measured in this study include; general habitat, vernacular name, scientific name, family, collection-number, collector and plant habitus, geographic position (altitude, latitude, and longitude) and ecological data. The morphological character and terminology were in accordance with Stearn (1988) and Mabberley (2008).

The vegetation was analyzed using the double plot method (Milliken 1998). A plot size of $10 \times 10 \mathrm{~m}$ was constructed with five (5) replicates placed separately to observe the species. A nested plot with $5 \times 5 \mathrm{~m}$ size was constructed in each plot to record the sampling species, while a $2 \times 2 \mathrm{~m}$ was constructed for the seedling and plant species understorey. Then, data of the abiotic factors such as; temperature, humidity, light intensity, and rainfall were obtained from secondary sources (Fauzan et al. 2018).

All the collected plant materials were identified at the Laboratory of Plant Biosystematic, Department of Biology, Faculty of Mathematics and Natural Sciences, Tadulako University, Indonesia. The plant specimens were identified using the specimen reference available at the Herbarium Celebence (CEB) of Tadulako University. These were determined by A.D Poulsen, a specialist on Zingiberaceae after which all the specimens were mounted, labeled, and kept at the CEB.

\section{Ethnobotany}

The ethnobotanical data such as the traditional utilization by local people (Topo Baria ethnic) were collected through direct interview with key informants such as; village leaders, religious leaders, traditional healers, and craft-people. The interviews were recorded through audio recorders and notebooks (Fathurrahman et al. 2016).
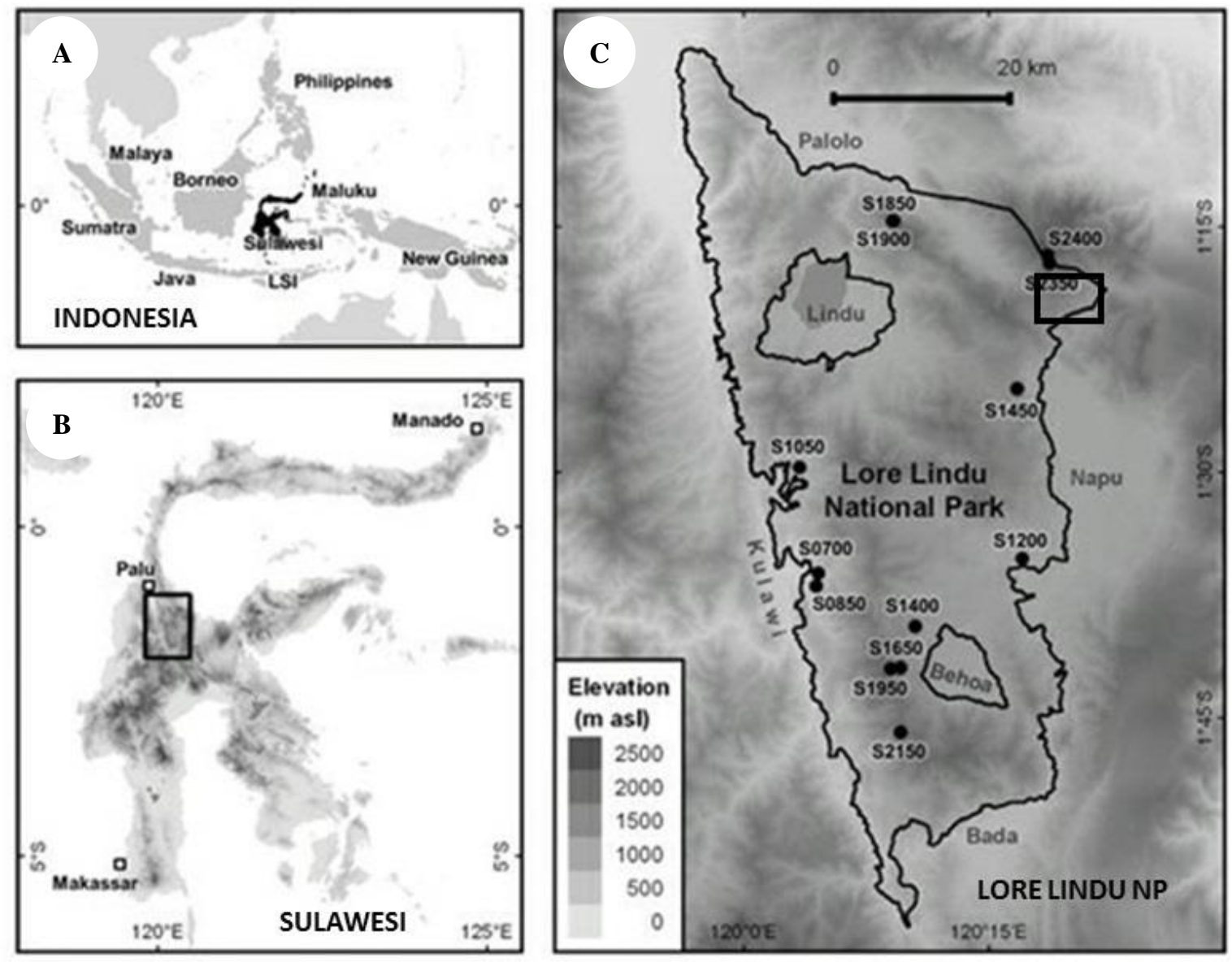

Figure 1. Map of the research site. A. Indonesian archipelago, B. Sulawesi island, C. Collecting localities are shown as a black rectangle in Lore Lindu National Park, Indonesia. 


\section{Plant extraction}

Plant extraction and phytochemical analyses of all parts of each species were conducted at the Laboratory of Phytochemistry, Department of Pharmacy, Faculty of Mathematics and Natural Sciences, Tadulako University. The extraction was carried out using maceration method as described in a previous study (Ramadanil et al. 2019). Then, vegetative organs such as leaves, rhizome, and pseudostem, as well as reproductive organs such as inflorescence and fruit of E. flexuosa, were washed in running tap water three times and cut into $3 \mathrm{~cm}$ pieces and again washed, soaked in running tap water for five minutes and then air-dried. Fresh and dried leaves, rhizomes, and inflorescence of the species were extracted with $95 \%$ ethanol through maceration. The extracts were filtered, evaporated in a vacuum evaporator, and lypolized to produce dry extract.

\section{Phytochemical evaluation}

The phytochemical compounds data of E. flexuosa such as alkaloid, phenolic, flavonoid, tannins, and saponins were obtained from secondary sources (Ramadanil et al. 2019).

\section{Qualitative test for antioxidant activity}

Qualitative test for antioxidant activity of sample was conducted using the thin layer chromatography (TLC) method with DPPH (2,2-diphenyl-1-picrylhydrazyl) as spraying reagent. The appearance of yellow spots on TLC plate after DPPH spraying indicates a positive result (Okawa et al. 2001; Moharram and Youseef 2014).

\section{Culture and growth media}

Pure cultures of experimental fungi were obtained from the Laboratory of Microbiology, Department of Biology, Faculty of Mathematics and Natural Sciences, Tadulako University, Palu. The pure culture of Candida albicans was maintained on Potato Dextrose Agar (PDA) medium. Fungal culture was further maintained by subculturing regularly on the same medium and stored at $4^{\circ} \mathrm{C}$ before it was used in this experiment. C. albicans was chosen based on its clinical and pharmacological importance (McCracken and Cowsan 1983). The fungal exists as a harmless commensal species in the gastrointestinal and genitourinary tract of healthy individuals (Nobile and Johnson 2015).

\section{Antifungal activity}

The antifungal activity was examined for hydroalcoholic extracts. Also, the antifungal activity of rhizome extracts against a pathogenic unicellular fungi, usually yeast, was investigated using the agar well diffusion method (Alzoreky and Nakahara 2003; Balouiri et al. 2016). The extract was screened for its antifungal activity against the $C$. albicans. Also, a set of four dilutions of E. flexuosa rhizome extract; 20, 40,60, and 80\%, as well as standard drugs were prepared in double-distilled water using nutrient agar tubes. Griseofulvin was used as the positive control was under similar conditions. The zones of growth inhibition for $C$. albicans around the disks were measured after 18 to 24 hours of incubation at $37^{\circ} \mathrm{C}$. The sensitivities of the fungi species to the plant extracts were determined by measuring the sizes of inhibitory zones (including the diameter of disk) on the agar surface around the disks.

\section{RESULTS AND DISCUSSION}

Detailed information on botanical description, habitat, and ecology, specimen examined, photographs, ethnobotany, phytochemistry content, and antifungal activity are provided in details as follow:

\section{Botanical description}

The perennial herb was about $4.2 \mathrm{~m}$ high, in loose clump, with about 8-12 in number, and 10-15 cm apart. Leafy stems were red or purple, about 3.8-4 m long, with up to 22 leaves per shoot, and $5 \mathrm{~cm}$ base diameter. The sheath color was yellowish to purple, with scattered hairs, pubescent near margin, margin mainly glabrous, integer, ligule of about 15-25 mm long, slightly entire, asymmetrical, black, apex villose, petiole 15-42 mm long, dark purple, densely villose on margin; lamina elongated elliptic, 51-70 cm long x $12.5-18 \mathrm{~cm}$ wide with ratio 4,2$5,6 \mathrm{~cm}$, green, midrib purple-red above and beneath, surface above with softly hairy, and apex acuminate. Inflorescence was $28-30 \mathrm{~cm}$ long, erect, arising from rhizome and receptacle $1.2-4 \mathrm{~cm}$ long. It was pink in the center, with 90-140 flowers, peduncle $4-14 \mathrm{~cm}$ long. The flowers were $4-6.5 \mathrm{~cm}$ long, erect at first, labellum ovate were $17-21 \times 3.5-5 \mathrm{~mm}$ long, the labellum bends outwards with age, calyx $2.8-3,4 \mathrm{~cm}$ long, apex stamen of 11-16 mm long, apex of corolla lobes $11-15 \mathrm{~mm}$, cream to pale pink at the base, bright pink towards the apex, corolla tube 2.6-3.5 $\mathrm{cm}$ long, stamen 12-16 mm long; filament 6-9 x 3-4 mm, with very broad base, with pink to cream color; anthers 5-7 $\mathrm{x}$ 3-4 mm long, with cream to pale pink in color. Infructescence with peduncle of about $8-12 \mathrm{~cm}$ long, bract, bracteole and calyx persistent, with 50-130 fruits per head, pedicel $0.3-1 \mathrm{~cm}$ long, fruit size of $2.3-3 \times 2-3 \mathrm{~cm}$, pyriform, soft spiny in upper half, reddish-brown, pubescent, seed 2-3 x 2-3 mm, black, rounded, and aril white. Rhizome with a stout of about $1-4 \mathrm{~cm}$ diameter, and pale yellowish brown to pale red in color.

Vernacular name: Karondo (Topo Baria languange, Sedoa, Lore Utara, Poso, Ramadanil Pitopang et al. 10041, Katimba (Pamona languange, Poso).

Specimen examined: Central Sulawesi, Poso District, Lore Utara Sub-district, Sedoa Village, Lore Lindu National Park, Danau Kalimpa'a, 01 ${ }^{\circ} 19.503$ 'S, $120^{\circ} 18.510^{\prime} \mathrm{E}, 1648 \mathrm{~m}$ elevation on October 5, 2019. Ramadanil Pitopang, Zulfadly \& Adrianus Tombi 10041 (CEB). 


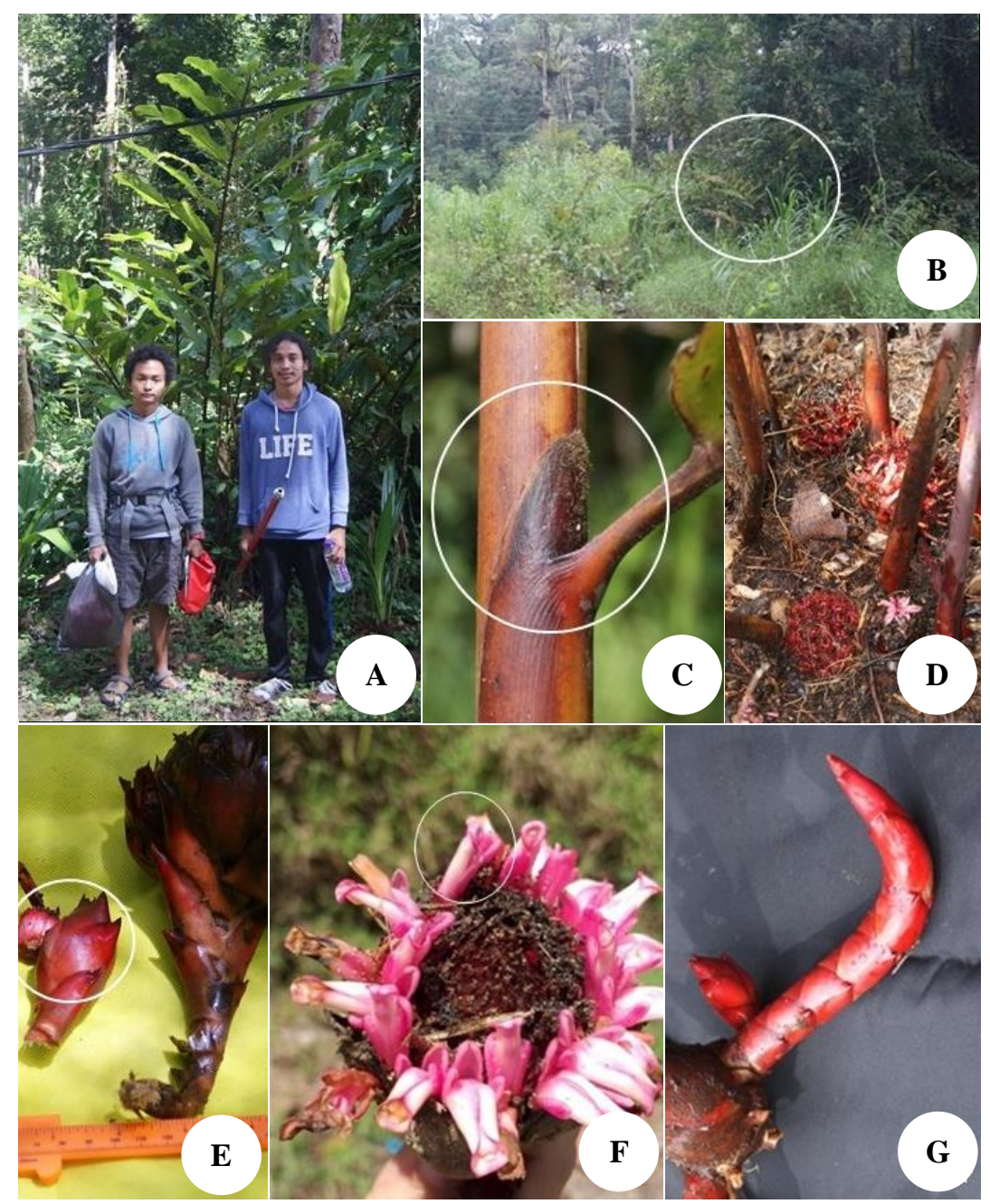

Figure 2. Etlingera flexuosa Poulsen shown behind the two young field assistants, B. Habitat of E. flexuosa. It grows in the montane forest of Lore Lindu National Park, Central Sulawesi, Indonesia on very wet soil near streams C. Ligule, D. Leafy shoot and flowering shoot, E. Infructescence, fruit in white circle, F. Inflorescence (flower) with labellum in white circle, G. Rhizome and its scale

\section{Habitat and ecology}

E. flexuosa grows on the very wet soil of the pristine evergreen montane forest, near streams at the altitude of 1200 - $1800 \mathrm{~m}$ a.s.l. This region usually receives an annual rainfall of about $1500-2000 \mathrm{~mm}$, with mean maximum temperature of $30-32^{\circ} \mathrm{C}$, while the mean minimum is usually around $18-21^{\circ} \mathrm{C}$, and average of relative humidity of about $59.62-81.74 \%$ (Fauzan et al. 2018) The analyses of the vegetation showed that the forest was dominated by the following species of trees; "haleka/kaha" (Castanopsis accuminatisima), "palili' (Lithocarpus havilandii), 'baka' (Cryptocarya crassinerviopsis), 'poni (Alsophila celebica), 'damar" (Agathis borneensis), 'pondo' (Pandanus sarasinorum), 'kayu cina" (Phylocladus hypophyllus), 'karunia' (Podocarpus neriifolius), Dacrycarpus imbricatus, 'Xanthomyrtus angustifolius, Acmena accuminatisima, Glochidion sp, 'leda' (Eucalyptus deglupta), Gordonia amboinensis, Polyosma integrifolia, Adinandra sp, Mallotus sp, and Erythrina subumbrans.

The pole-like species were mainly Mallotus barbatus, Aglaia argentea, Gordonia amboinensis, Litsea ferruginea,
Neolitsea javanica, Achronichia trifoliata, while the sapling species were mainly Acmena accuminatisima, Rapanea minutifolia, Lasianthus (Rubiaceae), Polyosma integrifolia (Escaloniaceae), Homalanthus populneus (Euphorbiaceae), and Callophyllum soulattri (Clusiaceae).

Herbs and understorey-like plant species were dominated by Impatiens mamasensis (Balsaminaceae), Selaginella sp. (Selaginellaceae), Polygonum barbatum (Polygonaceae), Elatostema sp (Urticaceae), Cyrtandra hypogaea (Gesneriaceae), Medinilla speciosa (Melastomataceae), Alpinia eremochlamys (Zingiberaceae), Alpinia rubricaulis (Zingiberaceae) and Gunnera macrophylla (Haloraganaceae)

In addition, some palms species were recorded and these include Pinanga caesia, Calamus macrosphaerion, Calamus koordersianus, Calamus viridis new spec, Calamus tambingensis spec. nov., Calamus didymocarpus, Calamus inops, Calamus posoanus, and Daemonorops sp. Some lianas species such as Tetrastigma sp, Rubus mollucanus (Rosaceae), and Racemosbamboo celebica (Poaceae) were also observed. 
Table 1. The traditional uses of Etlingera flexuosa by Topo Baria ethnic in Lore Utara Sub-district, Poso District, Central Sulawesi, Indonesia

\begin{tabular}{ll}
\hline Organ/part of plant & Uses \\
\hline Young leaves (shoot) & Eaten as vegetable \\
Leaves & Roof of hut \\
Rhizome & Medicine \\
Fruit & $\begin{array}{l}\text { For cooking fish dishes as flavor } \\
\text { enhancer }\end{array}$ \\
\hline
\end{tabular}

Table 2. Phytochemical component and antioxidant qualitative test of Etlingera flexuosa Poulsen (Zingiberaceae) from montane forest of Lore Lindu National Park, Central Sulawesi, Indonesia.

\begin{tabular}{lcccc}
\hline $\begin{array}{l}\text { Chemical } \\
\text { component } \\
\text { and }\end{array}$ & \multicolumn{4}{c}{ Organ } \\
\cline { 2 - 5 } $\begin{array}{l}\text { qualitative } \\
\text { antioxidant } \\
\text { test }\end{array}$ & Fruit & Leave & $\begin{array}{c}\text { Pseudostem/ } \\
\text { Leafsheat }\end{array}$ & Rhizome \\
\hline Flavonoid ${ }^{1)}$ & & & & \\
Tannin $^{1)}$ & Unevaluated & + & + & + \\
Saponin $^{1)}$ & + & + & - & + \\
Terpenoid $^{1)}$ & + & - & + & + \\
$\begin{array}{l}\text { Alkaloidd } \\
{ }^{1)}\end{array}$ & - & - & - & + \\
Steroid $^{1)}$ & + & + & - & - \\
$\begin{array}{l}\text { Qualitative } \\
\text { antioxidant }\end{array}$ & + & + & Unevaluated & Unevaluated \\
$($ DPPH) test & & & & \\
\hline Notes : ${ }^{1)}$ : Ramadanil et al. (2019), +: Present, - : Absent
\end{tabular}

Table 3. Summary statistics of inhibition zone of E. flexuosa rhizome extracts against $C$. albicans. Different lower case letter in the same column means significantly different values (DMRT test)

\begin{tabular}{lc}
\hline Treatment $(\%)$ & Zone of inhibition $(\mathbf{m m})$ \\
\hline 20 & $9 \pm 4.24 \mathrm{a}$ \\
40 & $13.5+0.71 \mathrm{a}$ \\
60 & $15+0.99 \mathrm{a}$ \\
80 & $19+2.83 \mathrm{~b}$ \\
Griseofulvin (positive control ) & $28.4 \pm 0.21 \mathrm{c}$ \\
\hline
\end{tabular}

\section{Ethnobotany}

E. flexuosa has been used traditionally by Topo Baria community, an indigenous ethnic living in Sedoa Village, Lore Utara Sub-district, Poso District, Central Sulawesi, Indonesia. The plant is locally known as "Karondo" in the community. Table 1 shows the data on the traditional utilization of E. flexuosa.

\section{Phytochemical component and antifungal activity}

The result of the phytochemical screening of crude ethanol extract of E. flexuosa is presented in Table 2. Six different chemical compounds were detected in the plant extract, namely; flavonoids, tannins, saponins, terpenoids, alkaloids, and steroids.
Flavonoids are found in rhizome, tannins are obtained in all the parts of the plant, while saponins are present in the leaves and rhizome. Additionally, terpenoids are not found in the leaves, alkaloids only detected in the rhizome, while steroids are only found in the leaves.

Based on Table 3, it is evident that the extract of $E$. flexuosa rhizome has a promising inhibitory power against C. albicans. Also, the highest inhibitory power of this extract to the yeast was at a concentration of $80 \%$, and statistically different from other treatments. However, there was no statistically significant difference among the extracts with concentrations of $20 \%, 40 \%$, and $60 \%$ in the inhibition of $C$. albicans.

The lowest concentration of E. flexuosa extract, at 20\%, still inhibited the growth of $C$. albicans. This means that the extract has the capacity to be used as herbal medicine for candidiasis, with little or no side effect.

\section{Discussions}

Etlingera flexuosa is one of flowering plant species described for the first time, from the province of Central Sulawesi, Indonesia (Poulsen 2012). It is a terrestrial herb with the ability to reach $5 \mathrm{~m}$ in height. This plant is very easy to recognize in the habitat due to its leaves sheath color usually yellowish to purple. The flowering shoots arise from the rhizome with pale pink flowers. The main characteristic of this species is its labellum bends which move outwardly with age.

The 42 species of Etlingera reported by Poulsen (2006) in Borneo are comparable to the 48 species identified in Sulawesi by (Poulsen 2012) in another study. Despite the fact that Borneo is about four times bigger than Sulawesi, the diversity of Etlingera in Sulawesi is indeed extraordinary. Moreover, 36 species from a total of 48 Etlingera of Sulawesi, which is about $75 \%$, are new (Poulsen 2012). These new species are as follows: Etlingera acanthoides, E. aculeatissima, E. aulocheilos, E. bicolor, E. biloba, E. borealis, E. bullata, E. calobates, E. canarina, E. caudata, E. chlorodonta, E. chrysantha, E. cylindrica, E. doliiformis, E. eburnea, E. echinulata, E. elegans, E. elliptica, E. flavovirens, E. grallata, E. hyalina, E. mendumiae, E. mucida, E. mucronata, E. orbiculata, E. orophilla, E. rubroloba, E. serrata, E. spinulosa, E. steringophora, E. translucens, E. tubilabrum, E. urophylla, E. xanthantha, E. yessiae and E. flexuosa (Poulsen 2012).

Based on literature review, 50 species of Etlingera have so far been recorded from Sulawesi island, including a new species named E. mamasarum, collected from Gunung Gandangdewata, Western part of Sulawesi (Ardiyani and Poulsen 2019), as well as E. megalocheilos, recorded from Pangi Binangga Nature Reserve, Parigi Moutong District, Central Sulawesi (Trimanto and Hapsari 2018).

Also, the field observation of E. flexuosa showed that it often grows in the pristine submontane and montane forest, sometimes in light and open condition or on the slope of natural disturbed forest at an altitude of 1500 -1700 m a.s.l. According to Cannon et al. (2007) and Culmsee and Pitopang (2009), Sulawesi has a steep topography with about $20 \%$ land cover above $1000 \mathrm{~m}$ a.s.l. Most of the forests are in good or old-growth conditions and are 
situated in mountain areas at montane elevations. The mountain forests in Sulawesi mainly cover the montane zone ranging from 1000 to $2400 \mathrm{~m}$ elevation.

The forest is dominated by Castanopsis accuminatisima (Fagaceae), Lithocarpus spp (Fagaceae), Podocarpus neriifolius (Podocarpaceae), Phylocladus hypophyllus (Podocarpaceae), Eucalyptus deglupta (Myrtaceae), as well as a number of endemic plant species such: Alsophila celebica, Impatiens mamasensis, Pandanus sarasinorum, Pinanga caesea, Calamus viridis, Calamus posoanus, Etlingera sublimata, and Etlingera acanthoides. According to Kessler et al. (2005), this region is categorized as Fagaceae forest, however, Culmsee et al. (2011) mentioned that the Fagaceae family makes up about $50 \%$ of the ground biomass in mountain forest of Central Sulawesi. Furthermore, about $20 \%$ of the total flora of Sulawesi are endemic species and the forest is also the habitat for some endemic Sulawesian fauna including; amphibians (Putri et al. 2019)

In the ethnobotany aspect, E. flexuosa has been extensively used by the local community of Topo Baria ethnic in various ways. The fruit is usually used as a flavor for cooking fish dishes and other foods. Its young shoot is edible as vegetable while the leaves are used as roofing material. This plant plays an important role in the traditional medicine of Topo Baria community. Its rhizome is usually used as traditional medicine for diarrhea.

Ginger plants are widely used as spices, condiments, and traditional medicine. The ethnomedicinal uses of the rhizomes and leaves of gingers were extensively reviewed by Ibrahim et al. (2007). The rhizomes could be eaten raw or cooked as vegetables and used as food flavoring ingredient (Larsen et al. 1999). According to Chan et al. (2011), the widely planted species include; Alpinia galanga, Curcuma longa, Curcuma xanthorrhiza, Zingiber officinale, Zingiber zerumbet, and Etlingera elatior. Pitopang et al. (2019) also reported 24 species of Zingiberaceae, some of which are endemic to Sulawesi, and used traditionally by three different local ethnics in Lore Lindu National Park.

Etlingera is one the genus of Zingiberaceae which has long been used in various communities for purposes such as traditional medicines, food, cosmetics, cooking spices, and ornaments. According to Chan et al. (2007), E. elatior is an aromatic plant widely used as traditional flavoring and for medicinal purposes. The inflorescence of E. elatior is edible, with nice taste in soup. The mixture of its leaves with other aromatic herbs in water is used by post-partum women for bathing to remove body odor. It is used as an alternative medicine for healing typhoid fever symptoms by Porehu community in Southeast Sulawesi (Sabilu et al. 2017). The flowers and fruit of E. elatior are used as a mixture of "cincang", traditional cuisine of Batak Karo sub-ethnic in North Sumatra. This is made from a mixture of cassava leaves (Manihot utilissima), banana pseudostem (Musa paradisiaca), and flowers of E. elatior (Silalahi and Nisyawati 2018).

The phytochemical analyses of the species showed the presence of some secondary metabolites such asflavonoids, tannins, saponins, terpenoids, alkaloids, and steroids (Ramadanil et al. 2019). Generally, secondary metabolites are chemical compounds produced by plants but are not involved in the normal growth, although often play vital roles in protecting the plants against herbivores and microorganism (Theis and Lerdau 2003; Alabri et al. 2014). Qualitative antioxidant tests showed that the extracts of fruit and leaves have antioxidant compounds characterized by yellow spots on TLC plate. This is caused by the presence of flavonoids, tannins, saponins, terpenoids, and steroids, which have been reported to possess antioxidant activity (Chan et al. 2007; 2011).

In addition, the inhibitory test showed that the rhizome extracts of E. flexuosa inhibited the growth of the $C$. albicans fungus. This is shown by the formation of inhibition zones due to antifungal activity. The E. flexuosa samples could be used as inhibitor agents for the growth of the unicellular yeast. The antimicrobial activity of $E$. flexuosa against fungal infections is due to the presence of chemical compounds such as flavonoid, tannin, saponin, terpenoid, and alkaloid in its rhizome (Ramadanil et al. 2019).

Bona et al. (2016) also reported the extraction of essential oils from different species of the plant such as; "minth", "lavender", "tea tree", "basil" and "winter savory." All these are more effective in inhibiting both the growth and the activity of $C$. albicans compared with the use of the main drugs.

Flavonoids are group of phenolic compounds widely distributed in plants. These compounds are considered as health-promoting and disease-preventing dietary supplements. Flavonoids have been clinically proven to exert some protective effects on animals against various disease conditions including cardiovascular issues and cancer. The compounds also possess antibacterial, antiviral, and anti-inflammatory effects. Also, alkaloids are secondary metabolites having heterocyclic nitrogen with antibacterial, antiviral, and anticancer activities (Altemimi et al. 2017). Some of the flavonoids which have been reported for these biological activities include; kaempferol 3-glucuronide, quercetin 3- glucuronide, quercetin 3glucoside, quercetin 3-rhamnoside, and (+)-catechin (Chan et al. 2007, 2011). According to Farhadi et al. (2018), flavonoids are a diverse group of natural products used in some traditional medicine systems for treating infectious diseases. Dong et al. (2008) revealed that the tannic acid in it destroys the integrity of cell wall.

In conclusion, the E. flexuosa plant is a terrestrial herb naturally present in Sulawesi, growing in the pristine evergreen montane forest, specifically on wet soil near the streams at the altitude of 1200 - $1800 \mathrm{~m}$ a.s.l. The forest is dominated by Fagaceae family and the E. flexuosa has been used traditionally by the Topo Baria community for different purposes. The plant is locally called "karondo" and its fruits are used for cooking fish dishes and as flavor enhancers. The young leaves are eaten raw or boiled as vegetable. Its rhizome is being used as medicine while the leaves are utilized to roof huts. The ethanol extract of $E$. flexosa rhizome contains some chemical components such as flavonoid, tannin, saponin, terpenoid, alkaloid, and antioxidant which inhibit the growth of the C. albicans. 


\section{ACKNOWLEDGEMENTS}

This research was funded by the Tadulako University, Palu, Indonesia through "Excellent Research Program 2020" with contract no. 4007/ UN.28/ KP/2020, allocated to the Faculty of Mathematics and Natural Sciences, Tadulako University. The authors are grateful to Zulfadly, Adrianus Tambi, Agung, and Sucipto Sudirman for assisting with the fieldwork. In addition, the efforts of Yeni Susilo, Vivi Purnamasari, and Sahlan are appreciated in helping with the samples prepared in the laboratory.

\section{REFERENCES}

Alabri THA, Al Musalami AHS, Hossain MA, Weli AM, Al-Riyami Q. 2014. Comparative study of phytochemical screening, antioxidant and antimicrobial capacities of fresh and dry leaves crude plant extracts of Datura metel L. J King Saud Univ Sci 26 (3): 237-243. DOI: 10.5530/pj.2019.11.80

Altemimi A, Lakhssassi N, Baharlouei A, Watson DG, Lightfoot DA. 2017. Phytochemicals: extraction, isolation, and identification of bioactive compounds from plant extracts. Plants 6 (42): 1-23.

Ardiyani M, Poulsen AD. 2019. An update of the genus Etlingera (Zingiberaceae) in Sulawesi including the description of a new species. Reinwardtia 18 (1): 31-42.

Alzoreky NS, Nakahara K. 2003. Antibacterial activity of extracts from some edible plants commonly consumed in Asia. Int $\mathbf{J}$ Food Microbiol 80 (3): 223-30.

Balouiri M, Sadiki M, Ibnsouda SK. 2016. Methods for in vitro evaluating antimicrobial activity: J Pharm Anal 6: 71-79.

Bona E, Cantamessa S, Pavan M, Novello G, Massa N, Rocchetti A, Berta G, Gamalero E. 2016. Sensitivity of Candida albicans to essential oils : are they an alternative to antifungal agents. J Appl Microb 121 (6) 1530-1545.

Cannon C, Summer HM, Hartig JR, Kessler PJA. 2007. Developing conservation priorities based on forest type, condition, and threats in a poorly known ecoregion: Sulawesi, Indonesia. Biotropica 39 (6): $747-$ 759.

Chan EWC, Lim YY, Omar M. 2007. Antioxidant and antibacterial activity of leaves of Etlingera species (Zingiberaceae) in Peninsular Malaysia. Food Chem 104 (4): 1586-1593.

Chan EWC, Ng VP, Tan VV, Low YY. 2011. Antioxidant and antibacterial properties of Alpinia galanga, Curcuma longa, and Etlingera elatior (Zingiberaceae). J Pharmacog 8 (22): 54-61.

Culmsee H, Pitopang R. 2009. Tree diversity in submontane and lower montane primary rain forest in Central Sulawesi. J Blum 54: 119-123.

Culmsee H, Pitopang R, Mangopo H, Sabir S. 2011. Tree diversity and phytogeographical patterns of tropical high mountain rain forests in Central Sulawesi, Indonesia. J Biodiv Conserv 20 (5): 1103-1123.

De Gusman CC, Siemonsma JS. 1999. Plant Resources of Southeast Asia. No.13. Spices. Prosea Foundation, Bogor. [Indonesian]

Dong G, Liu H, Yu X, Zhang X, Lu H, Zhou T, Cao J. 2018. Antimicrobial and anti-biofilm activity of tannic acid against Staphylococcus aureus. Nat Prod Res 32 (18): 2225-2228. DOI 10.1080/14786419.2017.1366485.

Farhadi F, Khameneh B, Iranshahi M, Iranshahy M. 2018. Antibacterial activity of flavonoids and their structure-activity relationship: An updated review. Phytother Res 33 (1): 13-40. DOI: 10.1002/ptr.6208

Fathurrahman, Nursanto J, Madjid A, Ramadanil R. 2016. Ethnobotanical study of Kaili Inde Tribe in Central Sulawesi Indonesia. Emirate J Food Agric 28 (5): 337- 347.
Fauzan DM, Pitopang R, Suleman S. 2018. Autekologi Impatiens mamasensis Utami \& Wiriad. di Kawasan Resort Tongoa Taman Nasional Lore Lindu Sulawesi Tengah. Biocelebes $12: 2$

Ibrahim H, Khalid N, Hussin K. 2007. Cultivated gingers of Peninsular Malaysia: Utilization, profile and micropropagation. Gard Bull Sing 59: 77-88.

Kessler M, Keßler PJA, Gradstein SR, Bach K, Schmul M, Pitopang R. 2005. Tree diversity in different land use systems in Central Sulawesi, Indonesia. Biodiv Conserv 14: 547-560. DOI: 10.1007/s10531-0043914-7.

Khaw SH. 2001. The genus Etlingera (Zingiberaceae) in Peninsular Malaysia including a new species. Gard Bull (Singap) 53: 191-239.

Larsen K, Ibrahim H, Khaw SH, Saw LG. 1999. Gingers of peninsular Malaysia and Singapore. Natural History Publications (Borneo).

Mabberley DJ. 2008. Mabberley's Plant-Books. A portable dictionary of plants, their classification and uses. Third edition. Cambridge University Press, Cambridge.

Milliken W. 1998. Structure and Composition of one hectare of Central Amazonian Tire Firma Forest. Biotropica 30 (4): 530-537.

McCracken WA, Cowsan RA. 1983. Clinical and Oral Microbiology. Hemisphere Publishing Corporation, New York.

Moharram HA, Youssef MM. 2014. Methods for determining the antioxidant activity: a review. Alex J Fd Sci Technol 11(1): 31-42.

Newman M, Lhuillier A, Poulsen AD. 2004. Checklist of the Zingiberaceae of Malesia. J Blum Suppl 16: 1-165.

Nobile CJ, Johnson AD. 2015. Candida albicans biofilm and human disease. Ann Rev Microbiol 69: 71-92. DOI: 10.1146/annurev-micro091014-104330.

Okawa M, Kinjo J, Nohara T, Ono M. 2001. DPPH (1,1-diphenyl -2picrylhydrazyl) radical scavenging activity of flavonoids obtained from some medicinal plants. Biol Pharm Bull 24 (10): 1202-1205. DOI: $10.1248 / \mathrm{bpb} .24 .1202$.

Poulsen AD. 2006. Etlingera of Borneo. Natural History Publications (Borneo), Kota Kinabalu.

Poulsen AD. 2012. Etlingera of Sulawesi. Natural History Publ., Kota Kinabalu.

Poulsen AD, Docot RVA. 2018. How many species of Etlingera (Zingiberaceae) are there in the Philippines. Edinb J Bot 76 (1): 3344

Putri AE, Fahri F, Annawaty A, Hamidy A. 2019. Ecological investigations and diversity of amphibians in Lake Kalimpa'a, Lore Lindu National Park, Central Sulawesi. J Nat Hist 53 (41-42): 25032516.

Pitopang R, Damry, Rusdi, Hamzah B, Zubair MS, Amar AL, Fathurrahman F, Basri Z, Poulsen AD. 2019. Diversity of Zingiberaceae and traditional uses by three indigenous group at Lore Lindu National Park, Central Sulawesi. In: J Phys: Conf Ser 1242 (1): 012039. IOP Publishing. DOI: https://doi.org/10.1088/1742$6596 / 1242 / 1 / 012039$

Ramadanil, Damry, Rusdi, Hamzah B, Zubair MS. 2019. Traditional usages and phytochemical screening of selected Zingiberaceae from Central Sulawesi, Indonesia. Pharmacognosy J 11 (3): 505-510.

Sabilu Y, Sahidin, Mukaddin A, Bittikaka Y, Tawa RA, Paddo J, Saptaputra SK. 2017. The utilization of Sikala (Etlingera elatior) as traditional medicine in Porehu Sub-district, North Kolaka District, Southeast Sulawesi Province, Indonesia. Adv Environ Biol 11 (9): 5 9

Silalahi M, Nisyawati. 2018. The ethnobotanical study of edible and medicinal plants in the home garden of Batak Karo sub-ethnic in North Sumatra, Indonesia. Biodiversitas 19 (1): 229-238.

Stearn WT. 1992. Botanical Latin. Fourth Edition. Timber Press, Portland, Oregon.

Theis N, Lerdau M. 2003. The evolution of function in plant secondary metabolite. Int J Plant Sci 164 (3 Suppl.): S93-S102.

Trimanto, Hapsari L. 2018. A new record of Etlingera megalocheilos (Griff) A.D Poulsen (Zingiberaceae) in Sulawesi, Indonesia. Biodiversitas 19 (4): 1227-1235. 